\title{
Phytoplankton Ability to Physiological Acclimatization and Genetic Adaptation to Global Warming
}

\author{
Eduardo Costas $^{1}$, Emma Huertas ${ }^{2}$, Beatriz Baselga-Cervera ${ }^{1}$, Camino García-Balboa ${ }^{1}$ \& Victoria López-Rodas ${ }^{1}$ \\ ${ }^{1}$ Genética, Facultad de Veterinaria, Universidad Complutense, Madrid, Spain \\ ${ }^{2}$ Instituto de Ciencias Marinas de Andalucía (CSIC), Cádiz, Spain \\ Correspondence: Victoria López-Rodas, Genética, Facultad de Veterinaria, Universidad Complutense, Av. Puerta \\ de Hierro s/n 28040 Madrid, Spain. Tel: 34-913-943-769. E-mail: vlrodas@ucm.es
}

Received: May 22, 2014 Accepted: June 12, 2014 Online Published: July 3, 2014

doi:10.5539/ijb.v6n4p24 URL: http://dx.doi.org/10.5539/ijb.v6n4p24

\begin{abstract}
Global warming represents a challenge to the survival of phytoplankton organisms, which are the basis of the aquatic food web and drive essential biogeochemical cycles. We propose a direct experimental research mimicking temperature-increasing scenarios as a novel way to explore the adaptation of phytoplankton to predicted future thermal scenarios. This vulnerability analysis of individual phytoplankton species to increased temperature is key to understand the impact of global warming on aquatic ecosystems. Considering the polyphyletic complexity of the phytoplankton community, we compare the adaptation ability of diverse phytoplankton species from oceanic, coastal and inland waters to global warming, evaluating the role played by physiological acclimatization and genetic adaptation. We found that physiological acclimatization allows survival under the lowest temperature increase. Afterwards pre-existing genetic variability allow some genotypes to survive. Finally, when the temperature rises to a certain threshold, only the occurrence of new mutations that confer thermal resistance assures adaptation. Our results also reveal diverse degrees of tolerance to temperature increase among the different functional groups of phytoplankton, with great inter-specific capacity for genetic adaptation.
\end{abstract}

Keywords: genetic adaptation, global warming, mutation, physiological acclimation, phytoplankton

\section{Introduction}

There is a broad consensus that global warming is a huge challenge for life worldwide if the present trend of temperature rise continues (Wrona et al., 2006). The majority of studies aimed at addressing the effects of climate change on ecosystems (e.g. Stenseth et al., 2002; Walther et al., 2002; Parmesan \& Yohe, 2003). Unfortunately, the microbial world has been scarcely analyzed. Consequently, the effects of climate change are best understood for the animals and plants that for organisms as abundant and important as microbes.

The adaptation studies of microbes to global warming are indispensable, as biogeochemical cycles depend of microbial activity. In particular, the tolerance of phytoplankton to global warming is extremely relevant as these organisms are the primary producers of aquatic ecosystems (Kirk, 1994; Falkowski, \& Raven, 1997), responsible for approximately half of the global net primary production (Behrenfeld et al., 2001). Phytoplankton also has a key role in biogeochemical cycles of carbon, nitrogen and phosphorus (Falkowski, Barber, \& Smetacek, 1998).

Although the lower trophic levels, such as the primary producers (phytoplankton) are usually considered less sensitive to environmental changes than their consumers or predators, alarming data suggest that phytoplankton biomass and productivity have declined since 1950 due to global warming (Behrenfeld et al., 2006; Boyce, Lewis, \& Worm, 2010).

In aquatic environments, phytoplankton experience temperature fluctuations on many different time-scales, but their ability to cope temperature changes could be compromised by the current rise in global temperature. The global temperature has increased around $0.6{ }^{\circ} \mathrm{C}$ during the last 100 years (Houghton et al., 2001), and current climate change models predict a further increase of $1-7^{\circ} \mathrm{C}$ by the year 2100 , relying on the $\mathrm{CO}_{2}$ emission (Magnuson et al., 1997; Meehl et al., 2007). However, greater changes are observed at higher northern latitudes, and most land areas are warming more rapidly than oceans (Intergovernmental Panel on Climate Change [IPCC], 2007). Under this rapid temperature increase phytoplankton mainly relies on mechanisms to cope with local 
environmental alterations, such as phenotypic plasticity and genetic adaptation, since the water mass circulation controls its spatial distribution.

A recent work investigated, at the level of individual species, the maximum capacity of adaptation to a gradual warming process in species belonging to various ecological niches, as well as comparing the inter-specific response as a function of the natural habitat and taxonomic group (Huertas, Rouco, López-Rodas, \& Costas, 2011). This work has given us a first insight into the response of phytoplankton communities to an expected environment alteration, for instance the temperature increase, that shows there is a high variability in the maximum capacity of adaptation associated with the taxonomic group and natural habitat. The experimental design used by Huertas et al. (2011), the so-called ratchet protocol, is the perfect tool to investigate maximum adaptation capability. However, this technique does not accurately discern between the mechanisms underlying the adaptation process (i.e. physiological acclimatization, pre-selective mutations or adaptive mutations) in waters whose temperature is increasing.

In this work, we carried out a mechanistic approach to disentangling causes of adaptation of phytoplankton to temperature increase. Based on classic concepts on adaptation to environmental change (Fisher, 1930; Lewontin, 1974; Sniegowski \& Lensky, 1995), and recent experimental work on adaptation of phytoplankton to global change (Garcia-Villada et al., 2004; López-Rodas, Maneiro, Lanzarot, Perdigones, \& Costas, 2008; Marvá, García-Balboa, Baselga-Cervera, \& Costas, 2014; García-Balboa et al., 2013), and warming (Flores-Moya et al., 2005; Huertas et al., 2011; Rouco, López-Rodas, Flores-Moya, \& Costas, 2011; Romero, López-Rodas, \& Costas, 2012), we hypothesise a conceptual model to explain phytoplankton adaptation to temperature increase:

i) under low levels of environmental stress, physiological acclimatization would be able to allow adaptation;

ii) when the temperature increases beyond the level of physiological adaptation, the pre-existing genetic variability could allow adaptation of some genotypes;

iii) finally, after a certain temperature threshold, only the occurrence of new thermal-resistant mutants can assure adaptation.

We analysed this conceptual model in various common phytoplankton species belonging to different taxonomic groups and isolated from continental water bodies, coastal waters and the Open Ocean. Our experimental model provides evidence for assessing how phytoplankters might respond and evolve to the temperatures envisaged for the near future. In addition, the nature of these resistant cells was investigated in an attempt to distinguish between temperature-resistant cells arising by direct and specific adaptation in response to thermal stress, versus temperature-resistant cells arising by rare spontaneous mutations occurring randomly before thermal stress.

\section{Methods}

\subsection{Species Used}

Twenty six different clonal cultures (i.e. strains) of Microcystis aeruginosa (Kützing) Lemmermann (Cyanobacteria), isolated from Doñana National Park (southern Spain), eighteen strains of Prorocentrum triestinum Schiller (Dinophyceae) isolated from the Atlantic cost (western Spain), twenty strains of Tetraselmis suecica (Kylin) Butcher (Prasinophyceae) isolated from coastal waters of east Sardinia (Italy), twenty four strains of Nitzschia closterium (Ehrenberg) Smith (Bacillariophyceae), isolated from Galicia (northwest Spain) and twelve strains of Isochrysis galbana Parke (Haptophyceae) isolated from the north-central Atlantic from the Algal Culture Collection of the Universidad Complutense (Madrid, Spain) were used. Natural thermal variation range during the year is summarized in Table 1 . 
Table 1. Main characteristics of the species studied. Temperature causing $100 \%$ growth inhibition was measured in ancestral populations before the fluctuation analysis. Growth inhibition was measured in triplicates of each species inoculated with $5 \times 10^{5}$ cells from mid-log exponentially growing cultures and exposed to increasing temperature (increase interval $=2{ }^{\circ} \mathrm{C}$ )

\begin{tabular}{|c|c|c|c|c|c|c|c|}
\hline $\begin{array}{c}\text { Isolation } \\
\text { Site }\end{array}$ & $\begin{array}{l}\text { Location } \\
\text { (Lat/long) }\end{array}$ & Species & $\begin{array}{c}\text { Isolation } \\
\text { temperature } \\
\left({ }^{\circ} \mathrm{C}\right)\end{array}$ & $\begin{array}{c}\text { Annual } \\
\text { temperature } \\
\text { range }\left({ }^{\circ} \mathrm{C}\right)\end{array}$ & $\begin{array}{c}\text { Temperature } \\
\text { causing } 100 \% \\
\text { growth } \\
\text { inhibition }\left({ }^{\circ} \mathrm{C}\right)\end{array}$ & $\begin{array}{c}\mathrm{N}^{\mathrm{o}} \text { of } \\
\text { strains } \\
\text { isolated }\end{array}$ & Micro-photographs \\
\hline CWB & $\begin{array}{c}037^{\circ} 005^{\prime} \\
\mathrm{N} 006^{\circ} \\
029^{\prime} \mathrm{W}\end{array}$ & $\begin{array}{l}\text { Microcystis } \\
\text { aeruginosa }\end{array}$ & 23 & $14-31$ & 32 & 26 & $\begin{array}{l}\because 0^{\circ} \\
\therefore\end{array}$ \\
\hline $\mathrm{COA}$ & $\begin{array}{c}036^{\circ} \\
007^{\prime} \mathrm{N} \\
006^{\circ} \\
023^{\prime} \mathrm{W}\end{array}$ & $\begin{array}{c}\text { Prorocentrum } \\
\text { triestinum }\end{array}$ & 21 & $15-24$ & 26 & 18 & \\
\hline $\mathrm{COA}$ & $\begin{array}{c}038^{\circ} \\
059^{\prime} \mathrm{N} \\
008^{\circ} \\
022^{\prime} \mathrm{E}\end{array}$ & $\begin{array}{c}\text { Tetraselmis } \\
\text { suecica }\end{array}$ & 22 & $13-25$ & 28 & 20 & \\
\hline $\mathrm{COA}$ & $\begin{array}{c}036^{\circ} \\
007^{\prime} \mathrm{N} \\
006^{\circ} \\
001^{\prime} \mathrm{W}\end{array}$ & $\begin{array}{l}\text { Nitzschia } \\
\text { closterium }\end{array}$ & 21 & $15-24$ & 28 & 24 & \\
\hline OPE & $\begin{array}{c}043^{\circ} \\
041^{\prime} \mathrm{N} \\
011^{\circ} \\
013^{\prime} \mathrm{W}\end{array}$ & $\begin{array}{c}\text { Isochrysis } \\
\text { galbana }\end{array}$ & 14 & $13-19$ & 28 & 12 & \\
\hline
\end{tabular}

Note. $\mathrm{CWB}=$ continental waterbodies $; \mathrm{COA}=$ coastal waters; $\mathrm{OPE}=$ open ocean.

\subsection{Disentangle the Causes of Phytoplankton Adaptation to Temperature Increase}

In order to assess the adaptation process that takes place in each of the species as a response to an increase of temperature, two different experiments were performed:

\subsubsection{Experiment 1}

The effect of warming was estimated by monitoring growth of different strain under increasing temperatures. We inoculated triplicates of each strain with $5 \times 10^{5}$ cells $\left(N_{0}\right)$ from mid-log exponentially growing cultures. Each strain was grown axenically in cell-culture flasks (Greiner; Bio-One Inc., Longwood, NJ, USA) with $20 \mathrm{ml}$ of $f 2$ medium (marine species) (Sigma-Aldrich, Germany) or BG11 medium (freshwater species) (Sigma-Aldrich, Germany) at $15,20,25,30$ and $35^{\circ} \mathrm{C}$ under $30 \mu \mathrm{mol} \mathrm{m} \mathrm{s}^{-2}$ light. Each strain was maintained for 20 days under these conditions. Afterwards, the final number of cells was blind counted (i.e. the person counting the test did not know the identity of the tested sample), using a Beckman (Brea, CA, USA) Z2 particle counter, except $M$. aeruginosa, which were counted using a Uriglass settling chambers (Biosiga, Cona, Italy) in an inverted microscope (Axiovert 35, Zeiss Oberkóchen, Germany) because cell aggregation prevents reliability of results using a particle counter in this species. We consider that a strain grow under a given temperature when $\mathrm{Nt}>5.5 \times$ $10^{5}$ cells. 
Two different results can be found, each of them being interpreted as the independent consequence of two different phenomena of adaptation:

i) If all the strains (genotypes) of a species are able to grow after a temperature increase, then a physiological acclimatization to temperature increase is enough to assures adaptation to that temperature (without effect among strains of genetic individual differences);

ii) In contrast, if only some strains (genotypes) of a species are able to growth after a temperature increase and others do not, then there are preexisting genetic variability among strains of this species in adaptation to increasing temperature.

\subsubsection{Experiment 2}

A temperature increase above a certain limit, the pre-existing variability is not capable to cope with high temperatures (i.e. all the strains of a species are unable to growth under this temperature). Once reached this limit temperature value, massive cell destruction takes place. However, some microalgae could survive at such high temperature as a result of two different mechanisms:

i) Adaptation induced directly by the temperature increases (i.e. as a result of post-selective adaptive mutations that occur in response to temperature increase).

ii) Adaptation not induced by temperature (i.e. as a result of selection of rare pre-selective spontaneous mutations that occur prior to temperature increase).

A modified Luria and Delbrück (1943) fluctuation analysis adapted for liquid cultures of microalgae (Lopez-Rodas et al., 2001; Costas et al., 2001) was performed using temperature as the selective agent (Figure 1). The fluctuation analysis combined set of experiments and statistical methodology to differentiate between adaptation as a result of post-selective mechanisms and adaptation as a result of pre-selective mechanisms. It consists of two different sets of experiments for each temperature and each strain analyzed (Figure 1). A clone of each species randomly chosen was used to perform the fluctuation analysis.

In set 1 experiment, around 90 culture flasks per species and temperature were used. Each culture was inoculated with a small enough number of cells to ensure the absence of pre-existing mutants in the culture $\left(N_{0} \approx 100\right.$ cells $)$ and growth in $5 \mathrm{ml}$ medium at $22{ }^{\circ} \mathrm{C}$ (non-selective conditions) until a final population of $N t \approx 10^{5}$ cells was reached. The cultures were subsequently exposed to temperatures of $30^{\circ} \mathrm{C}($ P. triestinum, $N$. closterium $)$ or $35^{\circ} \mathrm{C}$ (M. aeruginosa, T. suecica, I. galbana) as selective conditions. For set 2 (control) around 40 culture flasks containing $5 \mathrm{ml}$ of medium were inoculated with aliquots of $N t \approx 10^{5}$ cells from the same parental populations (growing at $22^{\circ} \mathrm{C}$ ) and exposed to selective conditions (temperatures of 30,35 and $40{ }^{\circ} \mathrm{C}$ ) simultaneously with set 1. Set 2 served as control group for the experimental error (Figure 1) and tracked the variance within the parental population (the inter-culture flask-to-flask variation), which was expected to be low.

Experiments and controls were maintained under the selective temperature value for 75 days prior to observation (to assure that only one mutant cell could generate enough progeny to be detected). The resistant cells in each culture were then counted.

According to Luria and Delbrück (1943), two different results can be found in the set 1 experiment, each of them being interpreted as the independent consequence of two distinct adaptation mechanisms (i.e. post-selective or pre-selective mechanisms, respectively):

i) If the occurrence of resistant cells is induced by the temperature increase (post-selective mechanisms), then every cell is likely to have the same possibility of developing resistance. Consequently, inter-culture (flask-to-flask) variation will be low (i.e. following the Poisson model, variance/mean $\approx 1$ ) and the variance in the number of cells per culture of set 1 should be similar to variance of set 2 (no fluctuation, Fig. 1).

ii) If the resistant cells arise by random mutations that occur spontaneously during the period in which the cultures grow from $\mathrm{N}_{0}$ to $\mathrm{Nt}$ (before the exposure to an increased temperature), then the inter-culture (flask-to-flask) variation would be high (i.e. not consistent with the Poisson model, variance/mean $>1$ ) and the variation in the number of cells per culture of set 1 should be significantly higher than those of set 2 (fluctuation, Figure 1). 


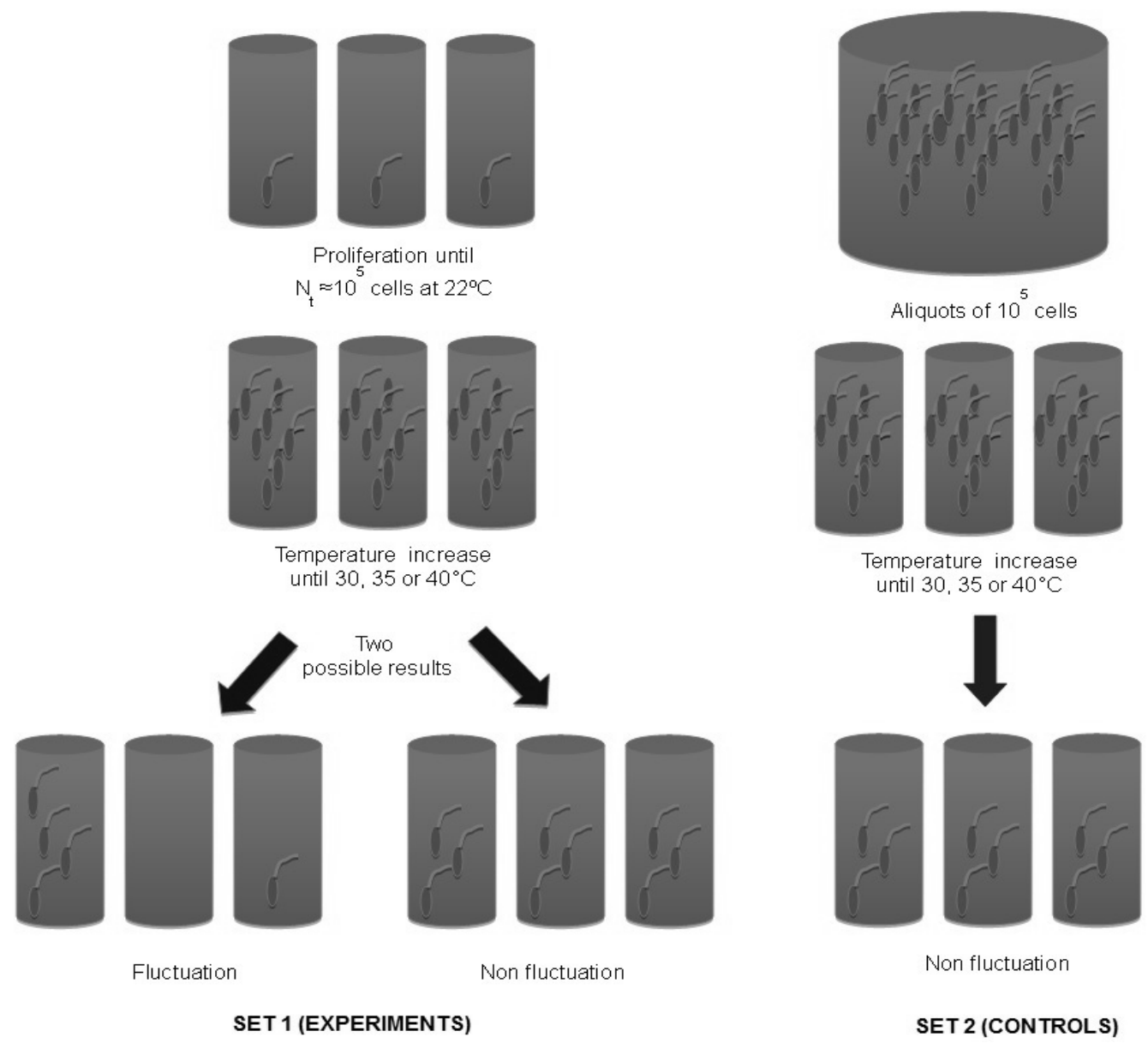

Figure 1. Possible results obtained in the fluctuation analysis

Set 1 experiments: different cultures (each started with $N_{0} \approx 100$ cells) were grown under non-selective temperature $\left(22^{\circ} \mathrm{C}\right)$ until a cell density of $N_{t}=10^{5}$ cells was reached, and then transferred to the selective temperatures. If fluctuation occurred, rare temperature-resistant mutants arose during the propagation of cultures under non-selective temperatures. The figure represents one mutational event early in the propagation of replicate 1 (therefore, the final density of temperature-resistant cells is high); one late in replicate 3 (therefore, the final density of temperature-resistant cells found is low); and replicate 2 without mutational events. In contrast, no fluctuation indicated that resistant cells arose as a response to selective temperature. Set 2 sampled the variance as an experimental control.

Obviously, another result ( 0 resistant cells in each culture) could also be found, indicating that non-adaptation to temperature increase took place.

In addition, fluctuation analysis allows estimation of the mutation rates of appearance of resistant cells. The proportion of cultures from set 1 showing non-resistant cells after temperature increase $\left(\mathrm{P}_{0}\right.$ estimator) was used to calculate the mutation rate $(\mu)$ as follows:

$$
\mathrm{P}_{0}=\mathrm{e}-\mu\left(\mathrm{N}_{\mathrm{t}}-\mathrm{N}_{0}\right)
$$

where $\mathrm{P}_{0}$ is the proportion of cultures with no resistant cells; $\mathrm{N}_{0}$ and $\mathrm{N}_{\mathrm{t}}$ represent the initial and the final cell densities, respectively; and $\mu$ stands for the mutation rate expressed in mutants per cell division (Luria \& Delbrück, 1943).

If, as expected, the mutation from a wild-type temperature-sensitive allele to a temperature-resistant allele is recurrent (Spiess, 1989), new temperature-resistant mutants will arise in each generation. Usually, these new resistant mutants are detrimental in fitness under nonselective conditions (Spiess, 1989) (i.e. normal temperature). Consequently, new temperature-resistant mutants will arise in each generation, but most of them will be eliminated sooner or later by natural selection under normal temperatures. Eventually, at any given time there will be a certain 
number of resistant mutants (at frequency q) that will not be eliminated. The balance between recurrent occurrence of temperature-resistant mutants (at rate $\mu$ ) and the rate of selective elimination of these mutants (at coefficient s) will determine the average number of such temperature-resistant mutants within the populations, according to the equation, (Kimura \& Maruyama, 1966):

$$
\mathrm{q}=\mu /(\mu+\mathrm{s})
$$

The selection coefficient was calculated according to the equation:

$$
\mathrm{s}=1-\left(\mathrm{m}_{\mathrm{r}} / \mathrm{m}_{\mathrm{s}}\right)
$$

where $m_{r}$ and $m_{s}$ are the Malthusian fitness (growth rates) of temperature-resistant and wild-type sensitive genotypes, respectively, measured in non-selective temperature (i.e. $22^{\circ} \mathrm{C}$ ).

\section{Results}

The role played by the different mechanisms that allow adaptation of phytoplankton to temperature increase (physiological acclimatization, adaptation based on pre-existing genetic variability and occurrence of new mutations that confer resistance) of phytoplankton organisms is summarized in Table 2.

\begin{tabular}{|c|c|c|}
\hline \multirow[b]{2}{*}{ Microcystis aeruginosa $\left(\right.$ at $\left.35^{\circ} \mathrm{C}\right)(\mathrm{CWB})$} & \multicolumn{2}{|c|}{$\mathrm{N}^{\mathrm{o}}$ of replicates } \\
\hline & Set 1 & Set 2 \\
\hline No. of replicate cultures & 90 & 35 \\
\hline \multicolumn{3}{|l|}{ No. of cultures containing the following no. of resistant cells: } \\
\hline 0 & 48 & 0 \\
\hline$<10^{-4}$ & 5 & 0 \\
\hline from $10^{-4}$ to $5 \cdot 10^{-4}$ & 4 & 0 \\
\hline from $5 \cdot 10^{-4}$ to $10^{-5}$ & 10 & 35 \\
\hline$>10^{-5}$ & 23 & 0 \\
\hline Variance/mean (of the no. of resistant cells per replicate) & 21 & 1.1 \\
\hline Fluctuation & yes & no \\
\hline \multicolumn{3}{|l|}{ Prorocentrum triestinum (at $\left.30^{\circ} \mathrm{C}\right)(\mathrm{COA})$} \\
\hline No. of replicate cultures & 50 & 30 \\
\hline \multicolumn{3}{|l|}{ No. of cultures containing the following no. of resistant cells: } \\
\hline 0 & 44 & 0 \\
\hline$<10^{-4}$ & 3 & 30 \\
\hline from $10^{-4}$ to $5 \cdot 10^{-4}$ & 2 & 0 \\
\hline from $5 \cdot 10^{-4}$ to $10^{-5}$ & 0 & 0 \\
\hline$>10^{-5}$ & 1 & 0 \\
\hline Variance/mean (of the no. of resistant cells per replicate) & 5.2 & 0.9 \\
\hline Fluctuation & yes & No \\
\hline \multicolumn{3}{|l|}{ Tetraselmis suecica $\left(\right.$ at $\left.35^{\circ} \mathrm{C}\right)(\mathrm{COA})$} \\
\hline No. of replicate cultures & 90 & 40 \\
\hline \multicolumn{3}{|l|}{ No. of cultures containing the following no. of resistant cells: } \\
\hline 0 & 78 & 0 \\
\hline$<10^{-4}$ & 2 & 40 \\
\hline from $10^{-4}$ to $5 \cdot 10^{-4}$ & 2 & 0 \\
\hline from $5 \cdot 10-4$ to $10^{-5}$ & 6 & 0 \\
\hline$>10^{-5}$ & 2 & 0 \\
\hline Variance/mean (of the no. of resistant cells per replicate) & 7.3 & 1.0 \\
\hline Fluctuation & yes & no \\
\hline
\end{tabular}

Table 2. Fluctuation analysis to study adaptation of different phytoplankton species to temperature increase. 
Table 2 (cont.)

\begin{tabular}{|c|c|c|}
\hline \multirow[b]{2}{*}{ Prorocentrum triestinum (at $\left.30^{\circ} \mathrm{C}\right)(\mathrm{COA})$} & \multicolumn{2}{|c|}{$\mathrm{N}^{\circ}$ of Replicates } \\
\hline & Set 1 & Set 2 \\
\hline No. of replicate cultures & 70 & 30 \\
\hline \multicolumn{3}{|l|}{ No. of cultures containing the following no. of resistant cells: } \\
\hline 0 & 65 & 0 \\
\hline$<10^{-4}$ & 3 & 0 \\
\hline from $10^{-4}$ to $5 \cdot 10^{-4}$ & 2 & 0 \\
\hline from $5 \cdot 10^{-4}$ to $10^{-5}$ & 0 & 35 \\
\hline$>10^{-5}$ & 0 & 0 \\
\hline Variance/mean (of the no. of resistant cells per replicate) & 2.3 & 1.1 \\
\hline Fluctuation & yes & No \\
\hline \multicolumn{3}{|l|}{ Isochrysis galbana (at $\left.35^{\circ} \mathrm{C}\right)(\mathrm{OPE})$} \\
\hline No. of replicate cultures & 65 & 35 \\
\hline \multicolumn{3}{|l|}{ No. of cultures containing the following no. of resistant cells: } \\
\hline 0 & 58 & 0 \\
\hline$<10^{-4}$ & 3 & 0 \\
\hline from $10^{-4}$ to $5 \cdot 10^{-4}$ & 3 & 35 \\
\hline from $5 \cdot 10^{-4}$ to $10^{-5}$ & 1 & 0 \\
\hline$>10^{-5}$ & 0 & 0 \\
\hline Variance/mean (of the no. of resistant cells per replicate) & 9.1 & 0.9 \\
\hline Fluctuation & Yes & No \\
\hline
\end{tabular}

The phytoplankton organisms are able to cope with slight temperature increases by mean of physiological acclimation. So, physiological acclimatization allow adaptation of $P$. triestium and $N$. closterium up to $20^{\circ} \mathrm{C}$ and of $M$. aeruginosa, T. suecica and I. galbana up to $25^{\circ} \mathrm{C}$ (Table 2). Until these temperatures all the clones (genotypes) of each species were able to grow.

When the temperature increases, only some strains (genotypes) of each species are able to proliferate (e.g. from the 26 strains of $M$. aeruginosa only 14 were able to grow at $30^{\circ} \mathrm{C}$, or from the 18 strains of $P$. triestinum only 5 were able to grow at $25^{\circ} \mathrm{C}$; Table 2). These differences existing among the different strains (genotypes) of each species denote the pre-existing genetic variability for temperature resistance.

If the temperature is further increased, the thresholds for physiological acclimatization and pre-existing genetic variability are exceeded and only the occurrence of new mutations could guarantee the survival of the species. When M. aeruginosa T. suecica and I. galbana were exposed to $35^{\circ} \mathrm{C}$ or P. triestium and $N$. closterium were exposed to $30{ }^{\circ} \mathrm{C}$ during the fluctuation experiments, the cell density was drastically reduced. This result was evident in all experimental cultures of sets 1 and 2, and for all species, owing to destruction of sensitive cells by the lethal effect of the temperature. However, after further incubation for 75 days, some cultures increased in density again, apparently due to growth of temperature-resistant variants. In the case of set 1, only some cultures showed appreciable cell growth. By contrast, all set 2 cultures recovered and temperature-resistant cells were detected in all the replicated tubes (Table 3). Fluctuations in the number of temperature-resistant cells were observed in set 1 experiment (variance/mean ratio $>1 ; P<0.001$ using $\mathrm{X}^{2}$ as a test of goodness of fit), in contrast with low fluctuation of set 2 controls (variance/mean ratio $\approx 1$, consistent with Poisson distribution; $P<0.05$ ). As the large fluctuation found in set 1 cultures is related to processes different from the sampling error, it could be inferred that temperature-resistant cells have arisen from rare, pre-selective spontaneous mutations occurring randomly during replication of organisms prior to exposure to the high temperatures, rather than by specific occurrence of resistant cells appearing in response to the temperature increase. The mutation rates from temperature sensitivity to temperature resistance ranged arround $10^{-6}$. 
Table 3. Mechanisms for adaptation (physiological acclimatization, adaptation based on pre-existing genetic variability and occurrence of new mutations that confer resistance) of phytoplankton organisms to temperature increase

\begin{tabular}{|c|c|c|c|c|c|c|}
\hline M. aeruginosa (26 strains analysed) & $15^{\circ} \mathrm{C}$ & $20^{\circ} \mathrm{C}$ & $25^{\circ} \mathrm{C}$ & $3^{\circ} \mathrm{C}$ & $35^{\circ} \mathrm{C}$ & $4^{\circ} \mathrm{C}$ \\
\hline \multicolumn{7}{|l|}{ Experiment 1: } \\
\hline Number of strains that were able to grow & 26 & 26 & 26 & 14 & 0 & 0 \\
\hline Adaptation based on physiological acclimatization & yes & yes & yes & no & no & no \\
\hline Adaptation based on physiological acclimatization & & & & yes & no & no \\
\hline \multicolumn{7}{|l|}{ Experiment 2: (more details are given in Table 3 ) } \\
\hline Fluctuation $(\mathrm{F}=\mathrm{CV}$ set1 / CV set 2$)$ & & & & & 21.0 & \\
\hline $\begin{array}{l}\text { Mutation rates from temperature sensitivity to } \\
\text { temperature resistance }\end{array}$ & & & & & $1.2 \times 10^{-6}$ & \\
\hline$s$ (coefficient of selection against resistant mutant & & & & & 0.51 & \\
\hline $\begin{array}{l}q \text { (frequency of thermal-resistant allele in } \\
\text { mutation-selection balance) }\end{array}$ & & & & & $1.2 \times 10^{-6}$ & \\
\hline $\begin{array}{l}\text { Adaptation based on the occurrence of new mutants that } \\
\text { confer resistance }\end{array}$ & & & & & yes & no \\
\hline
\end{tabular}

P. triestinum (18 strains analysed)

Experiment 1:

Number of strains that were able to grow

Adaptation based on physiological acclimatization

Adaptation based on physiological acclimatization

$\begin{array}{cccccc}18 & 18 & 5 & 0 & 0 & 0 \\ \text { yes } & \text { yes } & \text { no } & \text { no } & \text { no } & \text { no } \\ & & \text { yes } & \text { no } & \text { no } & \text { no }\end{array}$

Experiment 2: (more details are given in Table 3)

Fluctuation ( $\mathrm{F}=\mathrm{CV}$ set $1 / \mathrm{CV}$ set 2$)$

6.2

Mutation rates from temperature sensitivity to temperature resistance

$1.4 \times 10^{-6}$

$s$ (coefficient of selection against resistant mutant

$q$ (frequency of thermal-resistant allele in

mutation-selection balance)

$5.2 \times 10^{-6}$

Adaptation based on the occurrence of new mutants that confer resistance

yes

$\begin{array}{cccccc}20 & 20 & 20 & 15 & 0 & 0 \\ \text { Yes } & \text { yes } & \text { yes } & \text { no } & \text { no } & \text { no } \\ & & & \text { yes } & \text { no } & \text { no }\end{array}$

T. suecica (20 strains analysed)

Experiment 1:

Number of strains that were able to grow

Adaptation based on physiological acclimatization

Adaptation based on physiological acclimatization

Experiment 2: (more details are given in Table 3)

Fluctuation ( $\mathrm{F}=\mathrm{CV}$ set1 / CV set 2$)$

Mutation rates from temperature sensitivity to temperature resistance

$s$ (coefficient of selection against resistant mutant

$q$ (frequency of thermal-resistant allele in mutation-selection balance)

Adaptation based on the occurrence of new mutants that confer resistance

yes no

Table 3: (cont.) 


\begin{tabular}{|c|c|c|c|c|c|c|}
\hline N. closterium (24 strains analysed) & $15^{\circ} \mathrm{C}$ & $20^{\circ} \mathrm{C} \quad 2$ & $25^{\circ} \mathrm{C}$ & $30^{\circ} \mathrm{C}$ & $3^{\circ} \mathrm{C}$ & $40^{\circ} \mathrm{C}$ \\
\hline \multicolumn{7}{|l|}{ Experiment 1: } \\
\hline Number of strains that were able to grow & 24 & 24 & 9 & 0 & 0 & 0 \\
\hline Adaptation based on physiological acclimatization & yes & yes & no & no & no & no \\
\hline Adaptation based on physiological acclimatization & & & yes & no & no & no \\
\hline \multicolumn{7}{|l|}{ Experiment 2: (more details are given in Table 3) } \\
\hline Fluctuation $(\mathrm{F}=\mathrm{CV}$ set $1 / \mathrm{CV}$ set 2$)$ & & & & 2.0 & & \\
\hline $\begin{array}{l}\text { Mutation rates from temperature sensitivity to } \\
\text { temperature resistance }\end{array}$ & & & & $7.4 \times 10^{-6}$ & & \\
\hline$s$ (coefficient of selection against resistant mutant & & & & 0.36 & & \\
\hline $\begin{array}{l}q(\text { frequency of thermal-resistant allele in } \\
\text { mutation-selection balance) }\end{array}$ & & & & $2.0 \times 10^{-6}$ & & \\
\hline $\begin{array}{l}\text { Adaptation based on the occurrence of new mutants } \\
\text { that confer resistance }\end{array}$ & & & & yes & no & no \\
\hline \multicolumn{7}{|l|}{ I. galbana (12 strains analysed) } \\
\hline \multicolumn{7}{|l|}{ Experiment 1: } \\
\hline Number of strains that were able to grow & 12 & 12 & 12 & 8 & 0 & 0 \\
\hline Adaptation based on physiological acclimatization & yes & yes & yes & no & no & no \\
\hline Adaptation based on physiological acclimatization & & & & yes & no & no \\
\hline \multicolumn{7}{|l|}{ Experiment 2: (more details are given in Table 3) } \\
\hline Fluctuation $(\mathrm{F}=\mathrm{CV}$ set $1 / \mathrm{CV}$ set 2$)$ & & & & & 2.9 & \\
\hline $\begin{array}{l}\text { Mutation rates from temperature sensitivity to } \\
\text { temperature resistance }\end{array}$ & & & & & $3.4 \times 10^{-6}$ & \\
\hline$s$ (coefficient of selection against resistant mutant & & & & & 0.15 & \\
\hline $\begin{array}{l}q \text { (frequency of thermal-resistant allele in } \\
\text { mutation-selection balance) }\end{array}$ & & & & & $2.3 \times 10^{-6}$ & \\
\hline $\begin{array}{l}\text { Adaptation based on the occurrence of new mutants } \\
\text { that confer resistance }\end{array}$ & & & & & yes & no \\
\hline
\end{tabular}

Temperature-resistant mutants growing under normal temperatures showed lower fitness values than those found in the wild-type temperature sensitive strains. The relative values of fitness of resistant mutants and sensitive wild types were used to estimate the coefficient of selection $(s)$ of temperature-resistant mutants under normal temperature (Table 2). By using the values of $\mu$ and $s$, the frequency $(q)$ of resistant alleles in the wild-type population as a consequence of the balance between mutation and selection was calculated. As the result, the frequency of resistant alleles maintained in populations under normal temperature ranged between 1.2 temperature-resistant mutants per $10^{6}$ sensitive cells in M. aeruginosa and 6.6 temperature resistant mutants per $10^{6}$ sensitive cells in T. suecica (Table 3).

Obviously, temperature reaches a threshold at which organisms are unable to adapt (M. aeruginosa, T. suecica and I. galbana were unable to adapt to $40{ }^{\circ} \mathrm{C}$, whereas $P$. triestium and $N$. closterium were unable to adapt to $35^{\circ} \mathrm{C}$; Table 2).

\section{Discussion}

Very little is currently known on phytoplankton capabilities in response to climatic selection pressures under an adaptive point of view. Experimental research mimicking temperature-increasing scenarios can be considered a novel way to explore the adaptation of phytoplankton to predicted future thermal scenarios. Such experiments show that phytoplankton organisms can survive under increasing temperatures as a result of physiological adaptation (i.e. acclimatization). Physiological acclimatization allowed all the strains from the five analyzed species survive under a low temperature increase. Consequently, it can be concluded that usually the phenotypic plasticity must be able to cope to the global temperature increase during the last century (around $0.6^{\circ} \mathrm{C}$, Houghton et al., 2001), and perhaps allow adaptation to temperature increase under a low $\mathrm{CO}_{2}$ emission scenario (around $1.18^{\circ} \mathrm{C}$, Meehl et al., 2007). 
However, when environmental stress exceeds the physiological limits, survival depends exclusively on adaptive evolution supported by the occurrence genetic changes (Sniegowski \& Lenski, 1995). As the temperature rises above physiological acclimatization capacity, only the genetic mechanisms allows adaptation. It is commonly assumed that the preexisting genetic variability ensures the adaptation of the population (reviewed in Fisher, 1930 and Lewontin, 1975). All the species analyzed here presented genetic variability for thermal resistance. This preexisting genetic variability allows that some genotypes can be adapted to high temperature (i.e. some genotypes resistant until $5{ }^{\circ} \mathrm{C}$ more than others). About this, Costas, Baselga-Cervera, García-Balboa and López-Rodas, (2014) measured the heritability of fitness (i.e. proportion of variance in fitness that has genetic basis) under increasing temperatures, using an experimental quantitative genetic procedure suitable to phytoplankton populations. The results reveal that there is enough genetic variability in fitness within the population of phytoplankton to assure adaptation to temperature increase, even under a intermediate $\mathrm{CO}_{2}$ emission scenario.

It is accepted that short-term unpredictable stress is best met by physiological acclimatization, whereas continuous stress can be met by genetic adaptation (Bradshaw \& Hardwick, 1989). Conceivably, phytoplankton could face to low $\mathrm{CO}_{2}$ emission scenario by mean of physiological acclimatization, but if a warming is maintained over time, the phytoplankton populations could change genetically.

It is usually assumed that genetic adaptation is achieved slowly. However, recent studies are changing many preconceived notions about the adaptation of microalgae to extreme environments. So, microalgae can adapt very quickly to powerful algaecides such as copper (Garcia-Villada et al., 2004), modern herbicides like glyphosate, simazine and diquat (López-Rodas et al., 2007, Marva et al., 2010; Huertas et al., 2010) pesticides as lindane (Gonzalez et al., 2012), crude oil spills (Carrera-Martinez, Mateos-Sanz, López-Rodas, \& Costas, 2010; 2011; Romero-López et al., 2012), extremely contaminated mining waters (López-Rodas et al., 2008a; López-Rodas, Marva, Rouco, Costas, \& Flores-Moya, 2008b), extreme geothermal waters (Costas, Flores-Moya, \& López-Rodas, 2008, López-Rodas et al., 2009) and even uranium (Baselga-Cervera., López-Rodas, García-Balboa, Costas, 2013; Garcia-Balboa et al., 2013). In all these cases a single mutation is enough to achieve rapid adaptation. Adaptation to warming is much the same. When the temperature rises above a certain level, the pre-existing genetic variability is not able to ensure the adaptation, as in the case of M. aeruginosa T. suecica and I. galbana at $35{ }^{\circ} \mathrm{C}$ or $P$. triestium and $N$. closterium at $30{ }^{\circ} \mathrm{C}$. However, the occurrences of new mutations that confer thermal resistance allow phytoplankton adaption to temperature increase. Fluctuation analysis shows that thermal-resistant cells arose by rare spontaneous mutations, and not through direct and specific adaptation in response to temperature increase.

The mutation rates in the five strains of microalgae were found to be in the middle of the range of the mutations rates for resistance to algaecides, herbicides, pesticides, heavy metals, extreme environments and others (Costas et al., 2013; Costas \& López-Rodas., 2013; Fernandez-Arjona et al., 2013; Marvá et al., 2014; Romero-López, Costas, \& López-Rodas, 2014). Mutation is recurrent and new resistant mutants arise each generation, but most of them disappear eventually due to natural selection or chance. At any one time, the balance between the continuous appearance of mutants and their selective elimination determines the number of remaining temperature-resistant mutants in microalgae populations growing under their normal temperature. Accordingly, the population would be predominantly a line of wild-type temperature-sensitive genotypes, accompanied by a very small fraction of temperature-resistant clone lines. Therefore, the frequency of mutants present in the population should be enough to assure survival of phytoplankton populations in this age of global warming.

Additionally, recurrent exposure to changing temperatures could enhance the frequency of temperature-resistant alleles as the consequence of mutation-selection equilibrium. This could be very relevant in the case of inland waters species such as M. aeruginosa, or some coastal species such as T. suecica. Taking into account that all these species live in ecosystems where temperature variation is very common, our result seems coherent with the fact that the frequency of the resistant allele under growth in the normal temperature range was 10 times higher in these species than in P. triestinum and $N$. closterium, which are not naturally exposed to sudden changes in water temperature. For example, accurate circannual rhythms controlling the formation and germination in dinoflagellates cysts ensure that the free-living stages only face favourable environmental conditions (Costas \& Varela, 1989).

This capability of microalgae to adapt to temperature increase by means of mutation at one gene could have significant implications for the survival of microalgae under the temperature increase expected in a scenario of high $\mathrm{CO}_{2}$ emissions. These heat-resistant mutants present a detriment in fitness. Although phytoplankton can adapt to global heating, its growth and primary production will decrease, not only for oceanographic reasons, but because the heat-resistant genotypes that will survive are less productive. Furthermore, no adaptation is possible for neither of the species of study at $40{ }^{\circ} \mathrm{C}$, and only three out of five species (M. aeruginosa, T. suecica and $I$. 
galbana) were able to adapt at $35^{\circ} \mathrm{C}$. This information give us an idea of the temperature limit that phytoplankton could stand.

Although there still remain many uncertainties concerning the impact of global warming on phytoplankton communities, rare spontaneous mutations conferring resistance seem able to ensure the survival of many phytoplankton species. Warming also could induce a progressive replacement of the most sensitive functional phytoplankton genotypes and species by those that are more resistant. The impact of this possible scenario of temperature resistant mutants arising and replacing the sensible ones is virtually inscrutable.

\section{Acknowledgments}

This work has by been supported financially by the Spanish Ministry of Sciences and Innovation through the Grant CTM2012-34757. Special thanks are given to L. de Miguel for technical support.

\section{References}

Baselga-Cervera, B., López-Rodas, V., García-Balboa, C., \& Costas, E. (2013). Microalgae: first nuclear engineers? Anales de la Real Academia Nacional de Farmacia RANF, 79(4), 634-645.

Behrenfeld, M. J., O'Malley, R. T., Siegel, D. A., McClain, C. R., Sarmiento, J. L., Feldman, G. C., ... Boss, E. S. (2006). Climate-driven trends in contemporary ocean productivity. Nature, 444, 752-755. http://dx.doi.org/10.1038/nature05317

Behrenfeld, M. J., Randerson, J. T., McClain, C. R., Feldman, G. C., Los, S. O., Tucker, C. J., ... Pollack, N. H. (2001). Biospheric Primary Production during an ENSO Transition. Science, 29, 2594-2597. http://dx.doi.org/10.1126/science.1055071

Boyce, D., Lewis, M., \& Worm, B. (2010). Global phytoplankton decline over the past century. Nature, 466, 591-596. http://dx.doi.org/10.1038/nature09268

Bradshaw, A. D., \& Hardwick, K. (1989). Evolution and stress-genotype and phenotype components. Bioogical Journal of Linnean Society, 37, 137-155. http://dx.doi.org/10.1046/j.1095-8312.2002.00020.x

Carrera-Martinez, D., Mateos-Sanz, A., Lopez-Rodas, V., \& Costas, E., (2011). Adaptation of microalgae to a gradient of continuous petroleum contamination. Aquatic Toxicology, 101, 342-350. http://dx.doi.org/10. 1016/j.aquatox.2010.11.009

Carrera-Martínez, D., Mateos-Sanz, A., López-Rodas, V., \& Costas, E. (2010). Microalgae response to petroleum spill: An experimental model analyzing physiological and genetic response of Dunaliella tertiolecta (Chlorophyceae) to oil samples from the tanker Prestige. Aquatic Toxicology, 97, 151-159. http://dx.doi.org/ 10.1016/j.aquatox.2009.12.016

Costas, E., \& Lopez-Rodas., V., (2013). The role played for spontaneous mutation. Stress Biology of Cyanobacteria: Molecular Mechanisms to Cellular Responses. (pp. 307). CRC Press.

Costas, E., \& Varela, M. A. (1989). A Circannual rhythm in cysts formation and growth-rates in the dinoflagellate Scripsiella-Trochoidea Stein. Chronobiologia, 16, 265-270. Retrieved from http://europepmc.org/abstract/ $\mathrm{MED} / 2805945$

Costas, E., Baselga-Cervera, B., García-Balboa, C., \& López-Rodas, V. (2014). Estimating the genetic capability of different phytoplankton organisms to adapt to climate warning. Environmental Science group, Oceanography Open Access. (In press) http://dx.doi.org/10.4172/2332-2632.1000123

Costas, E., Carrillo, E., Ferrero, L.M., Agrelo, M., Garcia-Villada, L., Juste, J., \& López-Rodas, V. (2001). Mutation of algae from sensitivity to resistance against environmental selective agents: the ecological genetics of Dictyosphaerium chlorelloides (Chlorophyceae) under lethal doses of 3-(3,4-dichlorophenyl)-1,1 dimethylurea herbicide. Phycologia, 40, 391-398. http://dx.doi.org/10.2216/i0031-8884-40-5-391.1

Costas, E., Flores-Moya, A., \& López-Rodas, V. (2008). Rapid adaptation of algae to extreme environments (geothermal waters) by single mutation allows "Noah's Arks" for photosynthesizers during the Neoproterozoic "snowball Earth"? New Phytology, 189, 922-932. http://dx.doi.org/10.1111/j.1469-8137. 2008.02620.x

Costas, E., Gonzalez, R., López-Rodas, V., \& Huertas, E. (2013). Mutation of microalgae from antifouling sensitivity to antifouling resistence allows phytoplankton dispersal through ship's biofouling. Biological Invasions, 15(8), 1739-1750. http://dx.doi.org/ 10.1007/s10530-012-0405-8 
Falkowski, P. G., \& Raven, J. A. (1997). Aquatic Photosynthesis (pp. 375). Blackwell, Oxford. http://dx.doi.org/ 10.1016/S0176-1617(99)80078-9

Falkowski, P. G., Barber, R. T., \& Smetacek, V. (1998). Biogeochemical controls and feedbacks on ocean primary production. Science, 281, 200-206. http://dx.doi.org/ 10.1126/science.281.5374.200

Fernández-Arjona, M del Mar., Bañares-España, E., García-Sánchez, M. J., Hernández-López, M., López-Rodas, V., Costas, E., \& Flores-Moya, A. (2013). Disentangling mechanisms involved in the adaptation of photosynthetic microorganisms to the extreme sulphureous water from Los Baños de Vilo (S Spain). Microbial Ecology, 66(4),742-51. http://dx.doi.org/ 10.1007/s00248-013-0268-2

Fisher, R. A. (1930). The Genetical Theory of Natural Selection, Clarendon Press, Oxford.

Flores-Moya, A., Costas, E., Bañares-España, E., García-Villada, L., Altamirano, M., \& López-Rodas, V. (2005). Adaptation of Spirogyra insignis (Chlorophyta) to an extreme natural environment (sulphureous waters) through pre-selective mutations. New Phytology, 166, 655-661. http://dx.doi.org/ 10.1111/j.1469-8137.2005.01325.x

García-Balboa, C., Baselga-Cervera, B., García-Sanchez, A., Mariano-Igual, J., López-Rodas, V., \& Costas, E. (2013). Rapid adaptation of microalgae to extremely polluted waterbodies from uranium mining: an explanation of how the mesophilic organisms can rapidly colonize extremely toxic environments. Aquatic Toxicology, 144-145, 166-123. http://dx.doi.org/10.1016/j.aquatox.2013.10.003

Garcia-Villada, L., Rico, M., Altamirano, M., Sánchez, L., López-Rodas, V., \& Costas, E. (2004). Occurrence of copper resistant mutants in the toxic cyanobacteria Microcystis aeruginosa: characterization and future implications in the use of copper sulphate as algaecide. Water Research, 38, 2207-2213. http://dx.doi.org/10.1016/j.watres.2004.01.036

González, R., García-Balboa, C., Rouco, M., López-Rodas V., \& Costas, E. (2012). Adaptation of microalgae to lindane: a new approach for bioremediation. Aquatic Toxicology, 109, 25-32. http://dx.doi.org/10.1016/j.aquatox.2011.11.015

Houghton, J. T., Ding, Y., Griggs, D. J., Noguer, M., van der Linden, P. J., Dai, X., ... Johnson, C. A. (2001). IPCC, 2001: Climate Change 2001: The Scientific Basis. Contribution of Working Group I to the Third Assessment Report of the Intergovernmental Panel on Climate Change. Cambridge University Press.

Huertas, I. E., Rouco, M., López-Rodas, V., \& Costas E. (2010). Estimating the capability of different phytoplankton groups to adapt to contamination: herbicides will affect phytoplankton species differently. New Phytologist, 188, 478-487. http://dx.doi.org/ 10.1111/j.1469-8137.2010.03370.x

Huertas, I. E., Rouco, M., López-Rodas, V., \& Costas, E. (2011). Warming will affect phytoplankton differently: Evidence through a mechanistic approach. Proceedings of the Royal Society B, 278, 3534-3543. http://dx.doi.org/10.1098/rspb.2011.0160

Kimura, M., \& Maruyama, T. (1966). The mutational load with epistatic gene interactions in fitness. Genetics, 54, $1337-1351$.

Kirk, J. T. O. (1994). Optics of UV-B radiation in natural waters. Ergebnisse der Limnology, 43, 1-16.

Lewontin, R. C. (1974). The Genetic Basis of Evolutionary Change. New York and London: Columbia University Press.

Lewontin, R. C. (1975). The problem of genetic diversity. Harvey Lecture Series, 70, 1-20.

López-Rodas, V., Agrelo, M., Carrillo, E., Ferrero, L. M., Larrauri, A., Martín-Otero, L., \& Costas, E. (2001). Resistance of microalgae to modern water contaminants as the result of rare spontaneous mutations. European Journal of Phycology, 36, 179-190. http://dx.doi.org/10.1080/09670260110001735328

López-Rodas, V., Carrera-Martinez, D., Salgado, E., Mateos-Sanz, A., Baez, J. C., \& Costas, E. (2009). A fascinating example of microalgae adaptation to extreme crude oil contamination in a natural spill in Arroyo Minero, Río Negro, Argentina. Anales de la Real Academia Nacional de Farmacia RABF, 75, 883-899.

López-Rodas, V., Flores-Moya, A., Maneiro, E., Perdigones, N., Marva, F., Garcia, M. E., \& Costas, E. (2007). Resistance to glyphosate in the cyanobacterium Microcystis aeruginosa as a result of pre-selective mutations. Evolutionary Ecology, 21, 535-547. http://dx.doi.org/10.1007/s10682-006-9134-8

López-Rodas, V., Maneiro, E., Lanzarot, M. P., Perdigones, N., \& Costas, E. (2008a) Mass wildlife mortality due to cyanobacteria in the Doñana National Park, Spain. Veterinary Record, 162, 317-318. 
López-Rodas, V., Marva, F., Rouco, M., Costas, E., \& Flores-Moya, A. (2008b). Adaptation of the chlorophycean Dictyosphaerium chlorelloides to the stressful acidic, mine metal-rich waters from Aguas Agrias Stream (SWSpain) as result of pre-selective mutations. Chemosphere, 72, 703-707. http://dx.doi.org/10.1016/j.chemosphere.2008.04.009.

Luria, S., \& Delbrück, M., (1943). Mutations of bacteria from virus sensitivity to virus resistance. Genetics, 28 , 491-511. http://www.genetics.org/content/28/6/491.full.pdf + html

Magnuson, J. J., Webster, K. E., Assel, R. A., Bowser, C. J., Dillon, P. J., Eaton, J. G., ... Quinn, F. H. (1997). Potential effects of climate changes on aquatic systems: Laurentian Great Lakes and Precambrian Shield Region. Hydrological Processes, 11, 825-871. http://dx.doi.org/10.1002/(SICI)1099-1085(19970630)11:8<825::AID-HYP509>3.0.CO;2-G

Marvá, F., García-Balboa, C., Baselga-Cervera, B., \& Costas, E. (2014). Rapid adaptation of some phytoplankton species to osmium as a result of spontaneous mutations. Ecotoxicology, 23, 213-220. http://dx.doi.org/101007/810646-013-1164-8.

Marvá, F., López-Rodas, V., Rouco, M., Navarro, M., Toro, F. J., Costas, E., \& Flores-Moya, A. (2010). Adaptation of green microalgae to the herbicides simazine and diquat as result of pre-selective mutations. Aquatic Toxicology, 96, 130-134. http://dx.doi.org/10.1016/j.aquatox.2009.10.009

Meehl, G. A., Cove, C., Delworth, T., Latif, M., McAvaney, B., Mitchell, J. B., \& Taylor, K. E. (2007). The WCRP CMIP3 Multimodel Dataset: A New Era in Climate Change Research. Bulletin of the American Meteorological Society, 88, 1383-1394. http://dx.doi.org/10.1175/BAMS-88-9-1383

Parmesan, C., \& Yohe, G. (2003). A globally coherent fingerprint of climate change impacts across natural systems. Nature, 421, 37-42. http://dx.doi.org/ 10.1038/nature01286

Romero, J., López-Rodas, V., \& Costas, E. (2012). Estimating the capability of microalgae to physiological acclimatization and genetic adaptation to petroleum and diesel oil contamination. Aquatic Toxicology, 124, 227- 237. http://dx.doi.org/ 10.1016/j.aquatox.2012.08.001

Romero-López, J., Costas, E., \& Lopez-Rodas, V. (2014). Selected microalgae for petroleum bioremediation: towards a bio-depuration based on von Neumann -like machines. In J. B. Velázquez-Fernández \& S. Muñiz-Hernández (Eds), Bioremediation, Process, Challenges and Future Prospects (pp. 211-221). New York: NOVA Publishers.

Rouco, M., López-Rodas, V., Flores-Moya, A., \& Costas, E. (2011). Evolutionary changes in growth rate and toxin production in the cyanobacterium Microcystis aeruginosa under a scenario of eutrophication and temperature increase. Microbial Ecology, 62, 265-273. http://dx.doi.org/ 10.1007/s00248-011-9804-0

Sniegowski, P. D., \& Lenski, R. E. (1995). Mutation and adaptation: the directed mutation controversy in evolutionary perspective. Annual Review of Ecology, Evolutions, and Systematics, 26, 553-578. http://dx.doi.org/10.1146/annurev.es.26.110195.003005

Solomon, S. (Ed.). (2007). Climate change 2007-the physical science basis: Working group I contribution to the fourth assessment report of the IPCC (Vol. 4). Cambridge University Press.

Spiess, E. B. (1989). Genes in Populations (2th Ed.). New York: John Wiley.

Stenseth, N. C., Mysterud, A., Ottersen, G., Hurrell, J. W., Chan, K. S., \& Mauricio, L. (2002). Ecological Effects of Climate fluctuactions. Science, 297 (5585), 1292-1296. http://dx.doi.org/10.1126/science.1071281

Walther, G. R., Post, E., Convey, P., Menzel, A., Parmesan, C., Beebee, T. J., ... Bairlein, F. (2002). Ecological responses to recent climate change. Nature, 416, 389-395. http://dx.doi.org/ 10.1038/416389a

Wrona, F. J., Prowse, T. D., Reist, J. D., Hobbie, J. E., Lévesque, L. M. J., \& Vincent, W. F. (2006). Key Findings, Science Gaps and Policy Recommendations. Ambio, 35(7), 411-415. http://dx.doi.org/10.1579/0044-7447 (2006)35[411:KFSGAP]2.0.CO;2

\section{Copyrights}

Copyright for this article is retained by the author(s), with first publication rights granted to the journal.

This is an open-access article distributed under the terms and conditions of the Creative Commons Attribution license (http://creativecommons.org/licenses/by/3.0/). 